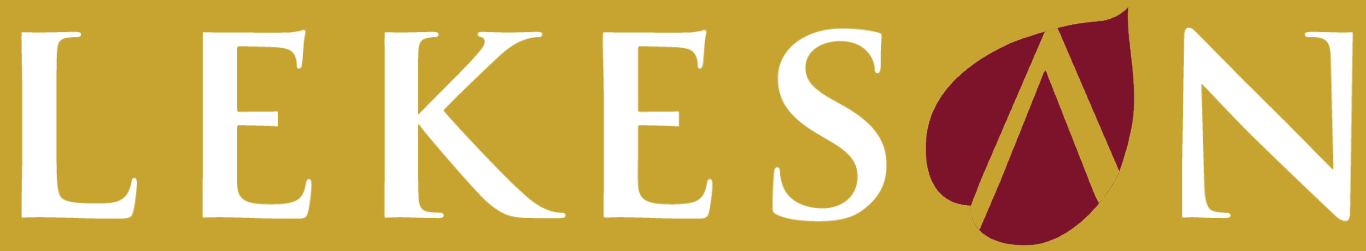

Interdisciplinary Journal of Asia Pacific Arts

VOLUME 2, ISSUE 1, APRIL 2019

\title{
Ecological Messages In The Ramayana Story Of The Wayang Purwa Shadow-Puppet Play
}

Djoko Sulaksono

Kundharu Saddhono 


\author{
LEKESAN: INTERDISCIPLINARY JOURNAL OF ASIA \\ PASIFIC ARTS \\ jurnal.isi-dps.ac.id \\ ISSN: 2598-2192 (online) \\ Editorial Office \\ Indonesia Institute of The Arts Denpasar \\ Jalan Nusa Indah Denpasar 80235 \\ Phone +62-361-227316 ext 159 Fax +62-361-236100 \\ E-mail : penerbitan@isi-dps.ac.id
}

LEKESAN: INTERDISCIPLINARY JOURNAL OF ASIA PASIFIC ARTS

Is a peer-reviewed journal

All rights reserved. Apart from fair dealing for the purposes of study, research, criticism, or review, as permitted under the applicable copyright legislation, no part of this work may be reproduced by any process without written permission from the publisher. For permissions and other inquiries, please contact penerbitan@isi-dps.ac.id

\section{ARTICLE SUBMISSION}

Lekesan: interdisciplinary journal of asia pasific arts is published 2 (two) times a year, i.e. april and october. To find out more about the submission process, please visit http://jurnal.isi-dps.ac.id/index.php/lekesan

\section{ARTICLE PROCESSING CHARGES}

Every article submitted to Lekesan will not have any 'Article Processing Charges'. This includes submitting, peer-reviewing, editing, publishing, maintaining and archiving, and allows immediate access to the full text versions of the articles

\section{SUBSCRIPTIONS}

Lekesan: interdisciplinary journal of asia pasific arts is available in electronic and print formats. Subscribe to gain access to content from the current year and the entire backlist.

Contact us penerbitan@isi-dps.ac.id

\section{CHIEF EDITOR}

Ni Luh Desi In Diana Sari, Indonesia Institute of The Art Denpasar, Indonesia

\section{EDITORIAL BOARDS}

I Wayan Dibia, Indonesia Institute of The Arts Denpasar, Indonesia

I Nyoman Sedana, Indonesia Institute of The Arts Denpasar, Indonesia

Nyoman Darma Putra, Udayana University, Indonesia I Gusti Ngurah Ardana, Indonesia Institute of The Arts Denpasar, Indonesia

Setiawan Sabana, Bandung Institute of Technology, Indonesia Deny Tri Ardianto, Sebelas Maret University, Indonesia M. Dwi Marianto, Indonesia Institute of the Arts Yogyakarta, Indonesia

Sumandiyo Hadi, Indonesia Institute of the Arts Yogyakarta, Indonesia

I Gusti Made Sutjaja, Indonesia

Adrian Vickers, Sydney University, Australia

Diane Butler, Udayana University, Indonesia Jean Couteau, Sarbonne University, France

Mary Louise Totton, Western Michigan University, USA

Faizah Sari, Surya University, Indonesia

\section{ADVISOR BOARDS}

I Gede Arya Sugiartha, Rector of Indonesia Institute of The Arts Denpasar, Indonesia

I Wayan Adnyana, Head of Institution of Research Community Service and Education Development, Indonesia Institute of The Arts Denpasar, Indonesia

\section{WEB ADMIN}

Agus Eka Aprianta

\section{SECRETARIAT}

I Gusti Ngurah Ardika

I Putu Agus Junianto

Ni Putu Nuri Astini

\section{FRIENDS OF LEKESAN}

Andy Mcneilly

Shigemi Sakakibara

\section{DISCLAIMER}

The authors, editors, and publisher will not accept any legal responsibility for any errors or omissions that may have been made in this publication. The publisher makes no warranty, express or implied, with respect to the material contained herein. 


\title{
Lekesan: Interdisciplinary Journal of Asia Pasific Arts
}

Journal homepage http://jurnal.isi-dps.ac.id/index.php/lekesan

\section{Ecological Messages In The Ramayana Story Of The Wayang Purwa Shadow-Puppet Play}

\author{
Djoko Sulaksono ${ }^{1}$, Kundharu Saddhono ${ }^{2}$
}

The aim of this research is to describe ecological messages in the Ramayana story of the wayang purwa shadow-puppet play. As a qualitative research, it used descriptive analysis techniques and ecology studies based on data derived from ecological content in the Ramayana story. Results from the analysis show that several ecological forms in the Ramayana story can be described and viewed from the interactions between characters in the story and fellow human beings, water, land, fire, air, plants and animals. These interactions point to a reciprocal relationship between living things and the environment. The results of this study enrich the treasure of knowledge in the field of literature and provide a picture for communities about the relationship between living things and the environment, which should be aligned with guidance within Javanese society. Through this research, communities are invited to respect each other's existence and living things in their surroundings. This is because everything in the world is believed to have its respective strengths and benefits.

Keywords: ecology, interaction, Ramayana

\footnotetext{
${ }^{1}$ Pendidikan Bahasa Jawa, Fakultas Keguruan

dan Ilmu Pendidikan, UNS,

Jl. Ir. Sutami no. 36 A Jebres, Surakarta,

57126, Indonesia

ciptaningmintaraga@yahoo.com
}

${ }^{2}$ Kajian Bahasa dan Budaya Jawa serta

Pengajarannya, LPPM UNS,

Jl. Ir. Sutami no. 36 A Jebres, Surakarta,

57126, Indonesia

LEKESAN: Interdiciplinary Journal of Asia Pasific Arts 


\section{INTRODUCTION}

Literature is a result of human creation, taste, and initiative that can represent people's lives in the real world. In this sense, literature is a miniature of the world we live in enriched with the imagination of the author. Through literature, individuals are able to capture a picture of the social, cultural, and environmental conditions in their stories. Images of life in literary works seek to teach people about various things.

Javanese literature has developed among Javanese people for a long time. In addition to functioning as an entertaining medium, literature has a very strategic role in the society, namely as a medium of moral learning in both oral and written forms of literature. Christianna $(2018$; 296) said that "despite the wide variety of Javanese culture, every its form reflects the personality and philosophy of Javanese life. Javanese culture is full of symbols that often teach about the wisdom of human life". As a form of literary work, the purwa shadow-puppet play is often used as a learning media for Javanese society. The stories featured in the purwa play revolve around the Ramayana and Mahabharata, both of which are used as a reference for the moral learning of Javanese society.

The Ramayana and Mahabharata stories are adapted from the epics of heroism in India. Incorporating the Ramayana and Mahabharata epics is inseparable from the history of the entry of Hinduism and Buddhism into the land of Java. The Ramayana and Mahabharata stories are inseparable from the belief system of the time. However, several variations in the two stories are the result of a form of adjustment in relation to the condition of the Javanese people. This can be seen from alterations in the story of Mahabharata. The Indian version of the Mahabharata tells about Dewi Drupadi who married five Pandhawas. This is certainly contrary to the culture in Javanese society so that the story is changed fundamentally in that Dewi Drupadi only married Yudhistira.

A lot of knowledge can be learned from a literary work. Some good things can also be interpreted easily in a literary work. Even, beauty in a literary work is quite interesting to learn. More than other details, a literary work depicts the storyline theme in terms of language, composition, and story details. One interesting aspect in a literary work is the depiction of interactions that occur in a story. Endraswara (2016: 17) translates literary ecology as a way of understanding environmental problems in the perspective of literature. Ecology is the study of interrelationships between living things in certain environments. Through these interactions, environmental ecosystems can be created in a balanced manner. Every living or non-living things in an environment has a very important role in an ecosystem.
The reciprocal relationships described in the background of the story must be arranged well so that it does not result in confusion. This becomes interesting to study because a good literary work is able to display real conditions in the community. These reciprocal relationships cannot be arranged randomly but rather smoothly. Rational interactions are described in detail to invite readers to be an integral part of the atmosphere that the author attempts to create.

Ecology in the Ramayana story is very interesting to be explored and studied. The reciprocal relationship between living things and the environment described in the Ramayana story becomes a learning opportunity for the community to respect each other in life. The interaction between living things and the environment is one of the teachings in Javanese society. Every human being must respect one another, along with other creatures, and the environment so that there exists a balance in life. In line with this background, the formulation of problem in this study deals with ecology that arises in the Purwa Ramayana shadow-puppet play story.

\section{METHODS}

This qualitative research used descriptive analysis techniques and ecology studies based on data derived from the content of the Purwa Ramayana shadow-puppet play. This study describes the interactions between the characters and the surrounding environment in the Ramayana story.

\section{RESULTS AND DISCUSSION}

\section{Ecology in the Literary Work}

Ecology is a term used to refer to the field of biological studies. Ecology is a study of the interaction between living things and certain environments. This is consistent with the formation of the word ecology itself, which is from the Greek words oikos and logos. The word oikos can be translated as habitat, home or place to live and live a life; while logos means science. Simply put, if the two words are combined, the word ecology can be translated as a study of the environment of living things. In short, Sulaksono \& Sadhono (2017: 4) emphasize that ecology is a branch of science related to an ecosystem that teaches about and studies the relationship and mutual dependence between a particular species or living things with their environments.

Everything in nature, both living and non-living things, must experience interactions that occur in an environment to form a unique tie of ecosystem. Aryandini (2002:1) adds that ecological studies portray the existence of a relation- 
ship between a particular species and its environment as a whole, and the relationship or the dependence of all parts of the earth in a systematic relationship through the geophysical, atmospheric and climate lower layers, plants and animals. Every object in a region has its own role. Interactions that are less balanced in an environment will result in a disruption of an ecosystem.

One example is the reciprocal relationship in the marine ecosystem. A shark is one of the predators whose existence is frightening. Some people might think that sea predators should be hunted and eliminated. Unfortunately, such a solution will only disrupt the balance in the marine ecosystem. The presence of predators in the ocean needs to be maintained properly. The loss of sharks in the marine ecosystem results in the increasing number of carnivorous fish populations sharply. The need for carnivorous fish to increase is also proportional to the increase of population. The fish will eat herbivorous fish in the ocean. The availability of small fish is incomparable to large fish populations that results in the exhaustion of the herbivorous fish. The absence of herbivorous fish causes an explosive number of algae in the ocean. Threfore, the balance of the marine ecosystem becomes considerably disrupted.

One of the teachings in Javanese society guides the community to maintain the balance of nature. Suyono (2009: 49) points out that humans are created to do more good deeds because every human has good attitudes, and positive mindsets. Thus, everything that happens in the universe goes as it should. Anshoriy \& Sudarsono (2008: 79) reveal that environmental philosophy is aware of the relationship between the environment and an ecology that pays attention to natural resources. Javanese culture teaches humans to not feel that they are superior entities who have the right to treat other creatures as inferior. Javanese society respects the existence of everything around it, both living and non-living objects. Everything created in this world has its own role so it must be respected and treated accordingly.

As a result, literature is able to encourage the public to understand various things in accordance with the content of the literature. Moreover, literature is able to capture a clear picture of the attitudes and patterns of interactions that must be and should not be undertaken by the community. Ecology and literary work have a very close relationship. Through the reading community, literary works can also teach about the ecology through stories. A literary work must be able to represent the condition of the community in real terms. Thus, it is recognized that literature can comprehensively reveal an event that involves the surrounding environment as an object of study (Sugiarti, 2017). The interaction patterns in a literary work can be used as a general illustration of how Javanese society interacts with its environment.

\section{Ecology in the Purwa Ramayana shadow- puppet play story}

In the performance of a Purwa Ramayana shadow-puppet play, a puppeteer always gives a picture of the state or the story environment in the form of janturan narration, pocapan language of recitation, and a prampogan troop of soldiers (Aryandini, 2002: 10-11) because an integral part of the shadow-puppet story is depicting chaos in the world. The chaos not only affects certain regions, but also the world of gods. The characteristic of the story in a Purwa Ramayana is that when the riots almost end, Punakawan clown figures appear; namely Semar, Gareng, Petruk, and Bagong. These figures deliver speeches to the community with words and funny acts. The Punakawan's humor is able to hypnotize the audience so that they melt in laughter yet still understand the words or lessons presented in the scene.

The janturan narration is a part of the shadow-puppet play that conveys a condition of a safe and peaceful area. This section is carried out with the accompaniment of a soft gamelan sound and the appearance of puppets on the screen. Nurhayati (2009: 106) mentions that the function of janturan is to describe the state of a country that is safe, peaceful, just, prosperous, and far from crime. The pocapan language of recitation can be interpreted as a dialogue as the puppeteer's speaking builds the dialogue between characters in the Purwa Ramayana shadow-puppet play, and with the female sindhen singers or the pengrawit musicians in the show. Meanwhile, the prampogan is a troop of soldiers that are usually used in the background of warfare. They can be distinguished as two types, namely in the form of human warriors and giant warriors.

Ecology exists in the Ramayana story especially in the interactions between characters and the nature. This happens because the characters in the story spend a lot of time in the forest at the request of Dewi Kekayi. A more complete ecology in the shadow-puppet play stories can be described, as follows:

\section{Humans with Humans}

As social beings, humans always interact with one another. The pattern of interactions in Javanese society is largely determined by social status and age. Such interaction patterns can be found in Purwa Ramayana shadow-puppet play stories. The interaction between Ramawijaya and his parents is an example of the Javanese community. Javanese society places parents as an obligatory part of life to be respected and obeyed. This is because parents have a very large role in caring for, guiding and shaping the character of children. Through the guidance of parents, a child can grow well and understand the norms of life. The re- 
spect of children to parents can be seen in the figure of Ramawijaya in the Ramayana story.

Ramawijaya is the son of Prabu Dasarata and Dewi Ragu and he also has two stepmothers, namely Dewi Kekayi and Dewi Sumitra. Although Dewi Kekayi and Dewi Sumitra are stepmothers, Ramawijaya still respects and considers them just like his own mother. Ramawijaya always respects and tries to take heed of the words of his mother and father. Ramawijaya's compliance with his parents cannot be doubted.

Prabu Dasarata initially intended to appoint Ramawijaya to be a king. But, this was opposed by Dewi Kekayi who requested that Barata be appointed as a king in accordance with Prabu Dasamuka's first appointment. Moreover, Dewi Kekayi also requested that Ramawijaya should be exiled into the forest. Knowing the request from his stepmother, Ramawijaya agreed to this as a form of devotion to parents. Although the petition was not a mild request, Ramawijaya remains obedient in implementing it sincerely.

The interaction between Ramayana and Dewi Shinta is well-illustrated in Purwa Ramayana shadow-puppet play stories. As a wife, Dewi Shinta is always loyal, obedient, and respects Ramawijaya as her husband. When Ramawijaya decided to go into the forest according to the request of his stepmother, Dewi Shinta sincerely followed her husband's departure. Dewi Shinta willingly left all the pleasures and conveniences of living in the palace to show her devotion to her husband. When Dewi Shinta was kidnapped by Rahwana, she retained her loyalty to Ramawijaya. Loyalty and obedience of the wife to the husband are the teachings of life in the Javanese community. The interaction between Dewi Shinta and Ramawijaya is a good example for the community.

Interactions between a brother and a sister are also depicted in Purwa Ramayana shadow-puppet play stories. This occurs between Gunawan Wibisana and Rahwana. As a younger brother, Gunawan tried to remind his brother of the mistakes he had made. One should remind each other about truths and misdeeds in a polite and non-patronizing way. Gunawan tried to explain that what Rahwana did was not true. The kidnapping of Dewi Shinta by Rahwana must be immediately solved.

Ecological irregularities can be found in this part. Interactions are inappropriate. As a human being, it is inappropriate to take the rights of others, such as in this case when Rahwana kidnapped Dewi Shinta. This deviation will ultimately disrupt the existing life balance. Gunawan asked Rahwana to immediately return Dewi Shinta to Ramawijaya, so that there would be no confusion in the country of Alengka. Rahwana was angry and did not want to hear Gunawan's advice and then expelled Gunawan from
Alengka. Ecological imbalances created huge riots in the country of Alengka.

Gunawan, who had left Alengka, went to see Ramawijaya. Gunawan felt that Ramawijaya was on the right side, so he decided to join the Ramawijaya army. Much information was conveyed by Gunawan to Ramawijaya. Ramawijaya believed the words and invited Gunawan to join his army. As a team, indeed they should work hand in hand to achieve the goal. Thanks to Gunawan's help, the Ramawijaya forces were able to defeat the troops led by Rahwana.

\section{Humans and Animals}

The balance of nature will develop well if humans pay attention to the reciprocal relationships with other creatures such as animals. In the Purwa Ramayana shadow-puppet play, this can be clearly seen. Good deeds done by humans will bear fruit of goodness as well. When Rahwana kidnapped Dewi Shinta, she was intercepted by a large bird called Jatayu. Jatayu tried his best to help Dewi Shinta escape the clutches of Rahwana. The struggle Jatayu made was not playing games. The fierce battle between Rahwana and Jatayu lasted for a long time. However, the victory is on Rahwana's side. Jatayu lost due to severe injuries and plucked feathers. Before he died, Jatayu met with Ramawijaya and then gave him some information.

Jatayu's sacrifice is great, even beyond reason. For the sake of others, Jatayu is willing to sacrifice his body and soul. In fact, this is more than just the services of Ramayana's parents in the past. Jatayu and Prabu Dasarata are good friends. Friends should help each other in terms of goodness. This can be seen in the figure of Jatayu. Reciprocal relationships can also be seen here. Prabu Dasarata's kindness is rewarded with kindness by Jatayu. Jatayu feels responsible for saving Prabu Dasarata's son-in-law.

The ecology between humans and animals also appears in the figure of Sugriwa. Sugriwa was a monkey king from the Kiskenda kingdom. In the story, Ramayan Sugriwa had two brothers, Dewi Anjani and Subali. The relationship between the three brothers was initially fine until one day Subali and Sugriwa liked the same woman, Dewi Tara. Subali and Sugriwa finally decided to fight against each other to determine who was more entitled to claim Dewi Tara. The battle was very fierce until finally Subali won. Sugriwa, who had lost, was clamped to a tree so he could no longer move. Based on the results of the fight, Subali had the right to marry Tara.

On the way to find Dewi Shinta, Ramawijaya met the figure of Sugriwa and did a good deed by helping to release Sugriwa from the tree. Ramawijaya's kindness was appreciated by Sugriwa. He was willing to help Ramawijaya save Dewi Shinta as long as Ramawijaya was willing to help him once again to defeat Subali. He was supported by Ramawijaya. 
The fierce battle between Subali and Sugriwa broke again, but with different results. This time it was won by Sugriwa with the help of Ramawijaya. As a sign of reward, Sugriwa helped Ramawijaya save Dewi Shinta from Rahwana's grip. The assistance given by Sugriwa was not jesting; he brought along his troops to help Ramawijaya.

\section{Humans and Plants}

Everything in the world has its own role including plants. Many benefits can be derived from plants. With the care of humans, plants can survive. In the food chain, plants occupy the most extreme position because of the ability to act as producers that are able to produce their own food. Some plants have other roles such as treating diseases, producing oxygen, and binding water and soil. The benefits produced from plants encourage humans to maintain and care for them. The human treatment toward plants is by spreading the forest so that it continues to thrive and maintain the plants. The attitude of humans who are reluctant to protect plants will have an impact on the extinction of plants, resulting in humans not being able to use them again.

In the Purwa Ramayana shadow-puppet play, during the journey to Alengka, Ramawijaya and other troops used plants as their food and supplies. A very fertile forest benefits them, especially monkey troops who like fruits. Mutual relations between plants and humans can be seen in this part. Forests as a source of life are always preserved. The Javanese community appreciates the existence of forests and the plants in it. Forests on earth must be conserved, and cannot be burned. Plant regeneration efforts should be much-needed if humans want to use forests.

The war in the land of Alengka is not an easy war. This was well-realized by Ramawijaya, such that he decided to meditate asking for help from the gods. In his hermitage, Batara Narada met Ramawijaya and gave him a maosadilata plant. The leaves were so powerful that his troops were revived from death. As an effort to keep the maosadilata plant alive and useful at any time, Ramawijaya planted it on Mount Maliawan. Ecology between humans and plants can be seen in this section. Plants that actually live by relying on nutrients must be treated properly by reforestation or replanting. Good plant cultivation allows plants to grow well, and thus used by humans again.

In the Ramayana story, maosadilata plants are used during the war in Alengka country. When the war was underway, Indrajit used the aji sirep which caused Ramawijaya and his troops to fall asleep. The only force of Ramawijaya who was not effected by the aji was Gunawan Wibisana. Gunawan attempted to dispel the ajian by issuing an ajian refusal then asked for Anoman to get the maosadilata plant on Mount Maliawan. Anoman, who did not know the shape and color of the plant, then brought some to Gunawan. After the plants were taken, Gunawan returned parts to Mount Maliawan where they should be. Ecology with the environment can be clearly seen here. Even though Anoman could have placed the plants everywhere, he still returned it to where it should be.

Besides using the maosadilata plant in warfare. Ramawijaya's troop used wood as a weapon in war. Well-maintained forests are able to provide everything, including providing wood for human needs. The troop used tree branches to repel forces from Alengka. Anoman with a tree-shaped weapon can defeat Patih Mangundara in the war. Patih Mangundara died in the hands of Anoman by being hit with a tree branch.

\section{Humans and Water}

Water is a crucial element on earth. All living things do need water. Plants that occupy the lowest position in the food chain cannot live without water. Although water is classified as an inanimate object, no creatures can live without water. Humans themselves mostly consist of water. About 60 to 80 per cent of the human body consists of water. Maintaining the quality and quantity of water in nature becomes an obligation for every individual, so that the existing ecosystem is not disturbed. This reciprocal relationship between humans and water can be seen in the Ramayana story.

On his way to Alengka, Ramawijaya was blocked by the sea. One of his efforts was to release his inherited arrow. Hot arrows can dry the ocean, so that many marine animals die. Knowing this, Batara Baruna became unhappy and asked that the arrow be revoked immediately. The drying ocean is not the right thing, as this can interfere with existing marine ecosystems. Batara Baruna advised Ramawijaya to make ponds as a way to cross the ocean. The ponds made by Ramawijaya did not damage the marine ecosystems, so that marine life can survive well. Humans should respect the sea; maintaining its cleanliness and integrity.

\section{Humans and Fire}

In Javanese culture, as a wadhag (body), humans are composed of four elements which are fire, soil, water and air. Fire has the nature of facing up, being able to spread, and to destroy. Even though fire looks dangerous, it can provide benefits to humans when used with good management according to the needs. Daily human activities cannot be separated from the existence of fire, both for cooking and warming the body. Absence of the element of fire on the earth can disrupt the balance of ecosystems. The element of fire also exists in the human body, yet certainly not in the form of a burning fire. Fire in the human body is used to burn calories. It is also one of the human self-factors related to emotions. Humans should be able to withstand their emotions. The greater is the human anger, the bigger is the magnitude of fire in them.

Ecology between humans and fire can be found in the Ramayana story. In one of the scenes, Ramawijaya orders 
Anoman to infiltrate and bring Dewi Shinta home from the country of Alengka. Anoman immediately obeyed the order and was able to meet with Dewi Shinta. However, Dewi Shinta did not want to go home if it was not Ramawijaya who picked her up. Before leaving, Anoman rioted in Alengka until he was finally captured by Alengka soldiers. Anoman did this intentionally as an effort to measure the strengths in the country. Anoman was put on trial before Rahwana and was sentenced to be burned to death in the city centre.

Miraculously the fire used to burn Anoman could not damage his body. Anoman survived without the slightest burn. As he was being burned in front of the public, Anoman chanted the aji that made his body grow to the size of a giant. He then dispersed the fire that was ignited to burn him so that it burned all of Alengka except for Maospati Park where Dewi Shinta lived. After measuring and burning Alengka's strengths, Anoman left to go to the place of Ramawijaya.

Human ecology and fire can also be viewed in the figure of Dewi Shinta in the Ramayana story. After a long journey of twelve years, finally Dewi Shinta was released from Rahwana's grip. She always maintains her purity despite having long been separated from Ramawijaya. Even many people are gossiping about Dewi Shinta; questioning her sanctity. As proof of her loyalty and to restore the trust of Ramawijaya and his people, Dewi Shinta asked for an obong self-will ceremony. This ceremony is held in an open place and can be witnessed by many people.

Shinta swore in the obong ceremony that if she burned it would mean that she was no longer holy because she betrayed Rahwana. But, if the fire could not burn Shinta's body, it would mean that she was pure and faithful to Ramawijaya. During the ceremony, when the fire was ignited, the blaze was so large that Shinta's body was engulfed by the flames. Amazingly, however, the flames could not burn Shinta's body. This is a true sign that Shinta's loyalty and chastity was extremely well-preserved. So, Ramwijaya accepted Shinta as his beloved wife.

\section{Humans and Soil}

Javanese culture recognizes the term 'a father of the motherland'. Land and water on earth are understood as a mother, while space is a father. Water and soil on earth have a very important role. From the soil springs the water of life; thus plants can live and humans can stand. Soil provides kindness for all and can be used in many ways.

In the Ramayana story, Rahwana has the Aji Pancasona or Rawa Rontek. This teaching was given to Rahwana by his teacher Resi Subali. Thanks to this initiation, Rahwana would not die when touching the ground. No matter how often Rahwana was defeated, if his body touches the ground, he would rise again to become a healthy giant.
Soil for Rahwana is a healer. This ajian is always used by Rahwana in every war, even in the war against Ramawijaya.

In the Ramayana story, Ramawijaya is basically able to kill Rahwana many times. However, Rahwana could rise again when he touched the ground. Overwhelmed, Ramawijaya then issued a powerful weapon called Kyai Dangu to end Rahwana's life. Kyai Dangu followed the route of Rahwana's departure until he finally decided to hide between two twin mountains. But, the two Twin Mountains suddenly converged and squeezed his body. Rahwana could not move to continue the fight, and thus lost the battle at the hands of Ramawijaya.

Ecology that occurs between humans and soil can also be seen in the figure of Shinta. After subjecting herself to the obong ceremony, Shinta was accepted by Ramawijaya again with open arms. However, the community still doubted her purity and their gossip in the public gradually shook Ramawijaya's belief in the sanctity and loyalty of Dewi Shinta. In a state of pregnancy, Dewi Shinta was asked to leave the palace by Ramawijaya. She chose to live alone in the forest while waiting for the birth of her child and suffered from sadness and loneliness. Finally, Dewi Shinta gave birth to two twins. Feeling insecure about the suffering she experienced, she swears that if she was not loyal to Ramawijaya, the earth would not accept her body. However, if she was faithful to Ramawijaya, the earth would accept her body. After speaking these words, the earth split into two and buried the body of Dewi Shinta in peace.

\section{Humans and Air}

It is well known that air also has a very large role in life. In fact, the human body is also composed of air. When breathing, humans inhale oxygen-containing air that circulates throughout the body and is released as carbon dioxide. Moving air also provides enormous benefits for the sustainability of an ecosystem such as providing coolness to every creature and bringing pollen to pistils so that flowers and fruits can be created. The wind carries clouds containing raindrops to a terrain, so that the land becomes fertile and beneficial for all creatures.

The ecology between humans and air can be found in the Ramayana story. During the battles in the country of Alengka, Ramawijaya and Laksmana used weapons in the form of wind arrows. Kumbakarna fought against Ramawijaya and, indeed, knew that Rahwana's deeds were wrong. The choice was taken not because Kumbakarna wanted to defend his brother. He fought for the people and their bloodshed. Kumbakarna felt disobedient if he betrayed his country by not defending his brother.

Kumabakarna died as a knight, fighting against Ramawijaya until death. Even though Kumbakarna struggled, both 
of his hands and feet were broken in the war. Seeing this, Ramawijaya released a wind arrow to end Kumbakarna's life. Kumbakarna died in the war as a hero of Alengka. Meanwhile, Indrajit also experienced losing a body part. While fighting against Laksmana, Indrajit lost his head, but his body still struggled and tried to overthrow his opponent. Laksmana immediately released a wind arrow and aimed it at the body of Indrajit. The troops who were hit by the wind arrow immediately fell and exhaled their last breath on the battlefield.

\section{CONCLUSION}

The Purwa Ramayana shadow-puppet play story contains several ecological messages. Through this story, the audience is able to understand the patterns of interactions between Javanese people and the surrounding nature which emphasizes that humans must respect everything in the universe, both living and inanimate things. The Javanese community believes that everything created by God has its respective roles. Arbitrary actions against other things in the world will only lead to life imbalances, which will have a negative impact on the universe.

The ecology or reciprocity that appears in the Purwa Ramayana shadow-puppet play stories can be grouped into seven forms, namely the ecology between humans and humans, humans and animals, humans and plants, humans and water, humans and soil, humans and fire, and humans and air. The ecology that occurs between humans and humans can be found in the figure of Ramawijaya who intervenes with his parents, his wife Dewi Shinta, and Gunawan who decides to join his army. The relationship between humans and humans can also be viewed in the figure of Gunawan and his brother Rahwana.

The ecology that occurs between humans and animals can be viewed in the interaction between Ramawijaya and the Jatayu bird and Sugriwa the king of monkeys. The ecology between humans and plants can be seen from the use of the Maosadilata plant as a cure for Ramawijaya's troops in Alengka country. In addition to using these plants, the Ramawijaya forces also used wood for weapons in the Alengka Bubrah war. The ecology between humans and water can be seen when Ramawijaya was about to cross the sea to help Dewi Shinta. Through that scene, the community is asked to preserve the water and its contents.

Human ecology with fire can be seen when Anoman was about to be burned alive in the country of Alengka. This can also be viewed in the obong ceremony that Dewi Shinta undergoes. The ecology between humans and air can be seen during the Alraha's Bubrah war when Ramawijaya released wind arrows to defeat Kumbakarna. This was also seen when Laksmana issued wind arrows to end the life of Indrajit. As for the ecology between humans and soil, Rahwana has an ajian so that he will not die if he touches the ground. However, he was badly defeated in the Alengka Bubrah scene due to being crushed by two mountains. Moreover, the ecology between humans and soil can also be viewed in the figure of Shinta who was buried in the ground according to her oath.

\section{REFERENCES}

Anshoriy, N., \& Sudarsono. (2008). Kearifan Lingkungan dalam Perspektif Budaya Jawa. Jakarta: Yayasan Obor Indonesia.

Aryandini, W. (2002). Wayang dan Lingkungan. Jakarta: Universitas Indonesia Press.

Christianna, A. (2018). The Representation Of Javanese Women In Damar Kurung Painting - Gresik Representasi Identitas Perempuan Jawa Dalam Ragam Hias Damar Kurung - Gresik. MUDRA Journal of Art and Culture, 33(3), 296. Retrieved from http://jurnal.isi-dps.ac.id/index.php/ mudra/article/view/376/265

Endraswara, S. (2016). Metodologi Penelitian Ekologi Sastra: Konsep, Langkah, dan Penerapan. Yogyakarta: CAPS.

Nurhayati, E. (2009). Sosiolinguistik: Kajian Kode Tutur dalam Wayang Kulit. Yogyakarta: Kanwa Publisher.

Sugiarti. (2017). 397 | Halaman. In Seminar Nasional Bahasa dan Sastra) (Vol. 1, p. 397). Retrieved from research-report.umm.ac.id/index.php/SENASBASA/article/ download/1737/1954

Sulaksono, D., \& Sadhono, K. (2017). Wayang Kulit Purwa berbasis Ekologi. Surakarta: CV. Dwija Amarta.

Suyono, R. . (2009). Ajaran Rahasia Orang Jawa. Yogyakarta: PT LkiS. 